\title{
Ab-initio modeling and experimental investigation of properties of ultra-high temperature solid solutions TaxZr1-xC
}

S. Vorotilo, K. Sidnov, I. Yu Mosyagin, A. V Khvan, E. A. Levashov, E. I Patsera and Igor Abrikosov

The self-archived postprint version of this journal article is available at Linköping University Institutional Repository (DiVA):

http:// urn.kb.se/ resolve?urn=urn:nbn:se:liu:diva-154089

N.B.: When citing this work, cite the original publication.

Vorotilo, S., Sidnov, K., Mosyagin, I. Yu, Khvan, A. V, Levashov, E. A., Patsera, E. I, Abrikosov, I., (2019), Ab-initio modeling and experimental investigation of properties of ultra-high temperature solid solutions TaxZr1-xC, J ournal of Alloys and Compounds, 778, 480-486.

https:// doi.org/ 10.1016/j.jallcom.2018.11.219

Original publication available at:

https:// doi.org/ 10.1016/j.jallcom.2018.11.219

Copyright: Elsevier

http:// www.elsevier.com/

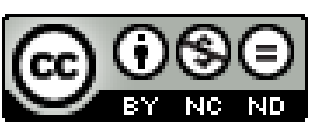




\title{
$A b$-initio modeling and experimental investigation of the properties of ultra-high temperature solid solutions $\operatorname{Ta}_{x} Z_{r_{1-x}} C$
}

S. Vorotiloa, K. Sidnov a,b I. Yu. Mosyagin a , A. V. Khvan ${ }^{a}$, E. A. Levashova, E.I. Patsera ${ }^{a}$, I.A. Abrikosov ${ }^{\mathrm{a}, \mathrm{c}}$

${ }^{a}$ National University of Science and Technology «MISIS», Leninsky pr. 4, 164, Moscow 119049, Russia

${ }^{b}$ Merzhanov Institute of Structural Macrokinetics and Materials Science, Russian Academy of Sciences, Academica Osipyana str, 8, Chernogolovka, Moscow Region 142432, Russia

${ }^{c}$ Department of Physics, Chemistry and Biology (IFM), Linkoping University, SE-581 83, Linkoping, Sweden

\begin{abstract}
Due to their high melting temperature, high-temperature oxidation resistance and outstanding mechanical properties, solid solutions $\mathrm{Ta}_{\mathrm{x}} \mathrm{Zr}_{1-\mathrm{x}} \mathrm{C}$ are a promising ultra-high temperature ceramic (UHTC). However, the accelerated knowledge-based development of UHTCs solid solutions requires reliable data regarding the properties of the solution phases in the whole interval of concentrations. In particular, there are contradictory reports regarding the existence of the miscibility gap in Ta-Zr-C system at the temperatures below $900{ }^{\circ} \mathrm{C}$. In this work, we carry out the $a b$-initio calculation of the thermodynamic properties of $\mathrm{Ta}_{\mathrm{x}} \mathrm{Zr}_{1-\mathrm{x}} \mathrm{C}$ alloys and demonstrate that the decomposition of the solid solutions into $\mathrm{TaC}$ and $\mathrm{ZrC}$ should not occur. We synthesize single-phase specimens with the composition $\mathrm{Ta}_{\mathrm{x}} \mathrm{Zr}_{1-\mathrm{x}} \mathrm{C}(\mathrm{x}=0.9,0.8,0.6,0.3)$ by self-propagating hightemperature synthesis (SHS) and anneal it for 40 hours. We do not observe any sign of the decomposition of the solid solution during the annealing, corroborating the conclusions obtained in theoretical simulations.
\end{abstract}

Keywords: UHTC; phase diagram; DFT; SHS; annealing 


\section{Introduction}

Ultra-high temperature ceramics (UHTCs), capable of retaining high mechanical properties and resisting high-temperature oxidation, have been the subject of active research [1-4]. Refractory compounds of transitional metals (Ta, $\mathrm{Nb}, \mathrm{Ti}, \mathrm{Zr}, \mathrm{Hf}$ ) usually serve as the basis for UHTCs [5]. Potential applications of UHTCs include hightemperature solar concentrators for renewable energy industry, barrier coatings, hard coatings [6-9]. $\mathrm{TaC}\left(\mathrm{T}_{\mathrm{m}}=3950^{\circ} \mathrm{C}\right)$ and $\mathrm{ZrC}\left(\mathrm{T}_{\mathrm{m}}=3420^{\circ} \mathrm{C}\right)$ are among the most refractory compounds known today [10-12]. Tantalum carbide has outstanding mechanical properties - elastic modulus $540 \mathrm{GPa}$, hardness $25 \mathrm{GPa}$, bending strength $800 \mathrm{MPa}$, hightemperature hardness 6.0 GPa [12-15].

Consequently, solid solutions in the $\mathrm{Me}^{5}-\mathrm{Me}^{4}-\mathrm{C}$ systems, where $\mathrm{Me}^{5}$ and $\mathrm{Me}^{4}$ are metals of the 4'th and 5'th group of the Periodic table, have attracted broad attention. Solid solutions (mostly with the composition $\mathrm{Ta}_{0.8} \mathrm{Zr}_{0.2} \mathrm{C}$ and $\mathrm{Ta}_{0.8} \mathrm{Hf}_{0.2} \mathrm{C}$ ) have been produced by hot-pressing of the mixture of monocarbide powders, sol-gel synthesis with the subsequent annealing, carbothermal co-reduction of the mixture of corresponding oxides and by self-propagating high-temperature synthesis (SHS), which is also known as combustion synthesis [16-18]. In comparison with the stoichiometric carbides, solid solutions have several advantages. Recently, Smith et al. [19] investigated the unusual deformation mechanism of solid solutions $\mathrm{Ta}_{\mathrm{x}} \mathrm{Hf}_{1-\mathrm{x}} \mathrm{C}$ using DFT calculations and experimental investigations. Unprecedented for B1 transitional metal carbides [10 $\overline{1}](111)$ dislocation and slip planes were indicated, which was attributed to the difference between the stacking fault energy for $\mathrm{Ta}_{\mathrm{x}} \mathrm{Hf}_{1-\mathrm{x}} \mathrm{C}$ and binary carbides $\mathrm{TaC}$ and HfC. Prospectively, tailoring of TaC-based solid solutions could enable the operation of five independent slip systems during the deformation and satisfy the requirements of von Mises plasticity criterion. That would ensure plastic deformation of the material instead of brittle fracture and pave the way to a drastic increase of the mechanical properties of the TaC-based materials. Hong and van de Walle [20] claimed that by adjusting the composition of the solid solution, one could control the Fermi level of the solid solution and tailor its melting temperature and coefficient of thermal expansion (CTE). For $\mathrm{Ta}_{\mathrm{x}} \mathrm{Hf}_{1-\mathrm{x}} \mathrm{C}$ solid solution, lower CTE was reported as compared to the TaC and HfC [21]. Moreover, synthesis of carbide solid solutions allows one to increase the oxidation resistance of the material. ZrC 
is characterized by low oxidation resistance at the temperatures below $1000{ }^{\circ} \mathrm{C}$ due to the spallation of the forming $\mathrm{ZrO}_{2}$ layer (“pesting” phenomenon). However, $\mathrm{ZrC}$ possesses high oxidation resistance at temperatures above $1000{ }^{\circ} \mathrm{C}$, because the $\mathrm{ZrO}_{2}$ layer retains its integrity and provides effective protection against oxidation. TaC, on the other hand, does not suffer from the "pesting", but the oxides in Ta-O system melt at relatively low temperatures $\left(1810^{\circ} \mathrm{C}\right)$ and do not form a protective layer. Therefore, $\mathrm{Ta}_{\mathrm{x}} \mathrm{Zr}_{1-\mathrm{x}} \mathrm{C}$ solid solutions have enhanced oxidation resistance in the whole temperature interval. Nowadays, the conventional approach to inhibit the oxidation of material is the addition of silicon-containing phases (such as $\mathrm{SiC}, \mathrm{MoSi}_{2}, \mathrm{TaSi}_{2}$ ). In case of rapid heating and cooling, such composites suffer from high thermal stresses due to the difference between CTEs of the comprising phases. Tailoring of solid solutions allows one to increase the oxidation resistance of the material without creating the additional thermal stresses [18]. Among the various methods that allow the synthesis of solid solution in Ta-Zr-C system, SHS is widely considered one of the most prospective [22, 23]. In this method, the exothermic effect of the formation of carbides of tantalum and zirconium is used as the main heat source. Temperatures up to $3000{ }^{\circ} \mathrm{C}$ can be achieved in the combustion front. At these temperatures, the solid diffusion accelerates enough to produce the single-phase $\mathrm{Ta}_{\mathrm{x}} \mathrm{Zr}_{1-\mathrm{x}} \mathrm{C}$ solid solutions with a homogeneous distribution of elements during the 1-3 s, which is unattainable by any other synthesis route. More detailed information regarding the SHS and its application to the synthesis of refractory materials is given elsewhere [18,22-24]. Latest developments in the SHS of solid solutions in Ta-Zr-C, Ta-Hf-C, TaTi-C systems are described in [18]. However, the absence of reliable data on the phase equilibria in the Ta-Zr-C system hinders the development and application of the related UHTCs. The available data concerning the $\operatorname{Ta}_{\mathrm{x}} \mathrm{Zr}_{1-\mathrm{x}} \mathrm{C}$ solid solutions are summarized below.

Gladyshevsky [25] analyzed an isothermal section of Ta-Zr-C diagram at $1450^{\circ} \mathrm{C}$ using metallography, thermal analysis, and XRD. Avgustinik and Ordan'yan [26] investigated the isothermal section at $2000^{\circ} \mathrm{C}$. Both sources reported the presence of the continuous solid solution between TaC and ZrC. Later, Rudy [27] made the most comprehensive experimental analysis of the Ta-Zr-C system in the temperature range between 1500 and $4000^{\circ} \mathrm{C}$. The presence of the continuous solid solution between $\mathrm{B} 1$ carbides $\mathrm{TaC}$ and $\mathrm{ZrC}$ was confirmed. However, Jangg [28] in 1968 first suggested the presence of the 
miscibility gap in the $\mathrm{B} 1$ solid solution $\mathrm{Ta}_{\mathrm{x}} \mathrm{Zr}_{1-\mathrm{x}} \mathrm{C}$. Unfortunately, the methodology of the preparation of $\operatorname{Ta}_{\mathrm{x}} \mathrm{Zr}_{1-\mathrm{x}} \mathrm{C}$ carbides was not discussed in details, nor was the incontrovertible experimental evidence of the miscibility gap presence reported. One should take into account that the employed auxiliary-metal-bath technique [28] can lead to contamination of the produced carbide samples by with the "auxiliary" metal. Also, there is no evidence that the examined samples achieved the equilibrium conditions during the synthesis.

Gusev et al. used calculated exchange energies in the subregular solution approximation and predicted the presence of a broad miscibility gap between $\mathrm{TaC}$ and $\mathrm{ZrC}$ in Ta-Zr-C system [29]. Their works are briefly summarized in [11]. On the contrary, Markström et al. [30] performed a thermodynamic assessment of Ta-Zr-C system solutions using $a b$ initio calculations of the enthalpies for static lattices (at $\mathrm{T}=0 \mathrm{~K}$ ) of the pure and mixed carbides and revealed that $\mathrm{Ta}_{\mathrm{x}} \mathrm{Zr}_{1-\mathrm{x}} \mathrm{C}$ carbides should be treated as ideal solid solutions. However, the Ta-Zr-C system was modeled in [30] using ordered supercells with L12 $\left(\mathrm{A}_{0.75} \mathrm{~B}_{0.25} \mathrm{C}\right.$ and $\left.\mathrm{A}_{0.25} \mathrm{~B}_{0.75} \mathrm{C}\right)$ and $\mathrm{L} 10\left(\mathrm{~A}_{0.5} \mathrm{~B}_{0.5} \mathrm{C}\right)$ type of ordering and thus differ from the disordered state.

Later Zhou et al. [31] in their thermodynamic assessment of the Ta-Zr-C system accepted the presence of the miscibility gap after $[28,29]$. Because the miscibility gap was not observed in the majority of experimental works [25-27], Zhou et al. presumed that the critical point of the miscibility gap should be below $930^{\circ} \mathrm{C}$ [31]. On the other hand, recent SEM and XRD analysis of TaC-ZrC and TaC-HfC diffusion pairs, performed by Ghaffari et al. [32], reported the presence of a single-phase solid solution in $\mathrm{TaC}-\mathrm{ZrC}$ pair. No miscibility gap was observed.

To summarize the discussion above, in Figure 1 we provide different published versions of TaC-ZrC phase diagram. It is noteworthy that both the international database NIST and Springer Landolt-Börnstein compendium [11] currently use the version of TaC-ZrC diagram proposed by Gusev [29] (Fig. 1). 


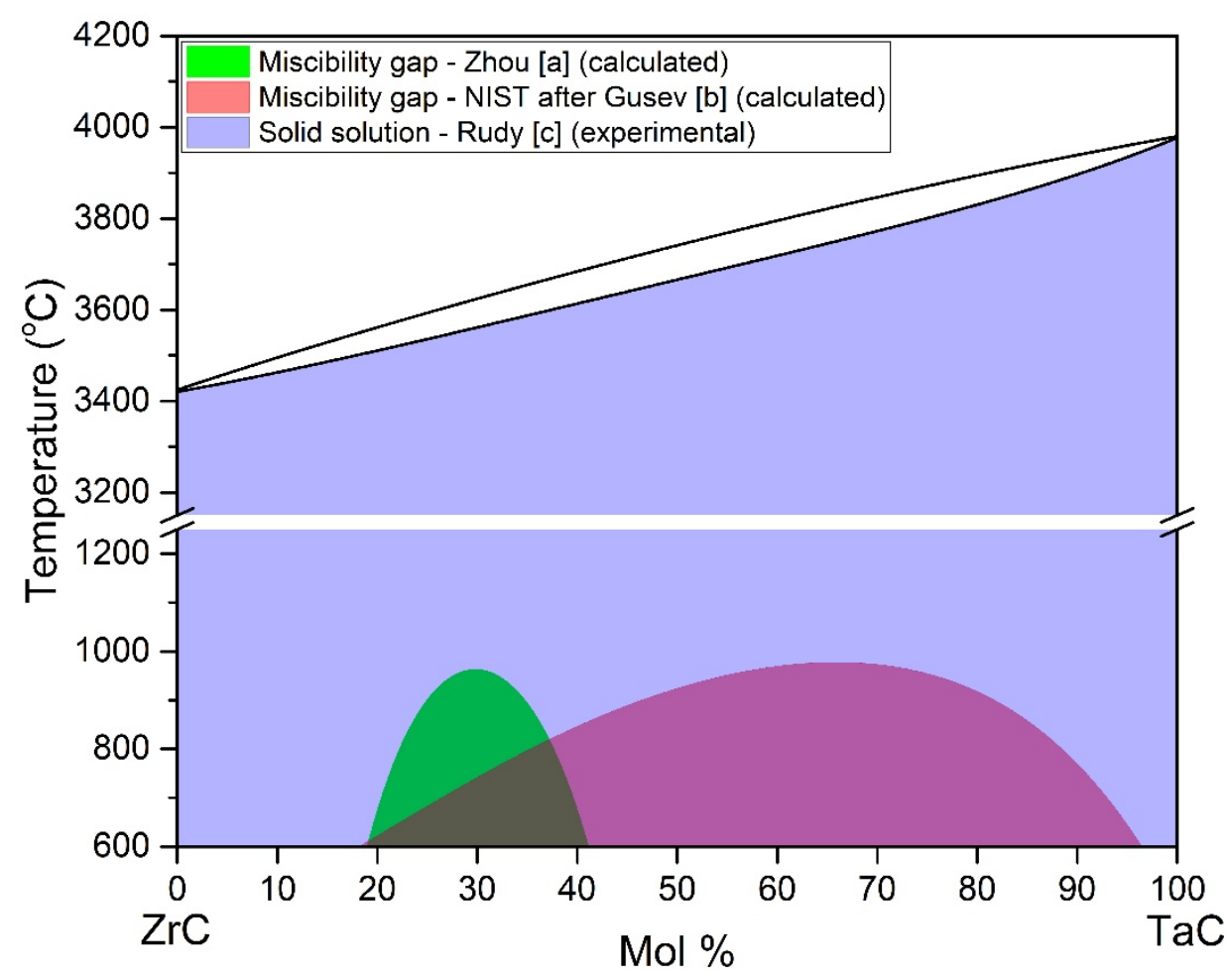

Fig. 1 - Phase diagram of the TaC-ZrC system with the miscibility gaps reported in various sources: a - [31]; b - [29]; c - [27]

Thus, the analysis of the literature reveals clear contradictions regarding the existence of the miscibility gap in the Ta-Zr-C system, as well as a lack of data concerning the properties of $\mathrm{Ta}_{x} \mathrm{Zr}_{1-\mathrm{x}} \mathrm{C}$ solid solutions. The stability of the solid solutions in the $\mathrm{Ta}_{\mathrm{x}} \mathrm{Zr}_{1-\mathrm{x}} \mathrm{C}$ system must be firmly proven if these materials are to be used as UHTCs because the decomposition of the solid solution could lead to the formation of the Zrdepleted areas and corresponding non-uniformity of the thermomechanical properties and oxidation resistance of the material.

For investigation of the properties of $\mathrm{Ta}_{\mathrm{x}} \mathrm{Zr}_{1-\mathrm{x}} \mathrm{C}$ solid solutions, two requirements have to be met:

1) Application of an adequate theoretical model and calculation techniques; 
2) Synthesis of single-phase homogeneous specimens of $\mathrm{Ta}_{\mathrm{x}} \mathrm{Zr}_{1-\mathrm{x}} \mathrm{C}$ solid solutions and corroboration of the results of calculations by experimental investigation.

$A b$ initio modeling, in particular the density functional theory (DFT), allows one to adequately calculate the properties of refractory materials, including the phase stability $[33,34]$ and influence of carbon vacancies $[35,36]$, while the SHS allows the production of single-phase specimens of $\operatorname{Ta}_{\mathrm{x}} \mathrm{Zr}_{1-\mathrm{x}} \mathrm{C}$ solid solutions with the homogeneous distribution of elements [17-18]. Considering the numerous advantages of $\operatorname{Ta}_{x} Z_{1-x} C$ ceramics as well as recent increase of interest towards UHTCs and solid solutions of refractory phases (often referred as high-entropy ceramics) from the broad community of materials scientists and engineers, our aim is to perform $a b$ initio calculations and experimental investigations of the $\operatorname{Ta}_{\mathrm{x}} \mathrm{Zr}_{1-\mathrm{x}} \mathrm{C}$ solid solutions in a broad concentration range and to address the issue of the presence or absence of the miscibility gap in the system.

\section{Methods}

\subsection{Computational details}

In this work, the mixing enthalpy of $\mathrm{TaC}$ and $\mathrm{ZrC}$ was calculated in the framework of the DFT using the projector augmented wave method (PAW) [37], implemented in the VASP 5.3 software (Vienna Ab-Initio Simulation Package) [38-41]. Calculations were performed at $\mathrm{T}=0 \mathrm{~K}$, using static approximation and neglecting the effect of lattice vibrations. The effects of exchange and correlation were considered in the framework of the generalized gradient approximation (GGA) approximation with the Perdew-BurkeErnzerhof (PBE) parameterization [42]. We used PAW potentials with the following number of valence electrons: $\mathrm{Ta}-11, \mathrm{Zr}-12$, C - 4. We employed a structural optimization with the full relaxation of the ions positions as well as the volume of the supercells. B1 structures with 8-atoms unit cell (Fm-3m space group) were generated for the $\mathrm{TaC}$ and $\mathrm{ZrC}$. To take into consideration the effects of chemical disorder of $\mathrm{Ta}_{\mathrm{x}} \mathrm{Zr}_{1-}$ ${ }_{\mathrm{x}} \mathrm{C}$ solid solutions, we used supercells on $\mathrm{B} 1$ underlying crystal lattice generated using the Special Quasirandom Structure (SQS) approach [43,44] (Table 1). Integration over the Brillouin zone was performed using the 10x10x10 k-points grid for the TaC and $\mathrm{ZrC}$ 
and using the $8 \times 8 \times 8$ k-points grid for the cells of $\operatorname{Ta}_{x} Z_{1-x} C$ solid solutions, generated according to the Monkhorst-Pack scheme [45]. For the calculation of the mixing enthalpy, it is necessary to use the total energies (see Eq.1), calculated using the same cut-off energy [45]. The cut-off energy of $800 \mathrm{eV}$ ensured the convergence of the calculated energies and was used in all the calculations.

Table 1 - Supercells used for the calculations. The distribution of $\mathrm{Zr}$ and Ta atoms in the SQS of solid solutions with B1 rock salt structure is defined and described by B. Alling et al. [46].

\begin{tabular}{|l|l|l|}
\hline Composition & $\begin{array}{l}\text { ZrC content in the solid } \\
\text { solution, at.\% }\end{array}$ & $\begin{array}{l}\text { Number of atoms in SQS- } \\
\text { supercells }\end{array}$ \\
\hline $\mathrm{Ta}_{28} \mathrm{Zr}_{4} \mathrm{C}_{32}$ & 12,5 & 64 \\
\hline $\mathrm{Ta}_{18} \mathrm{Zr}_{6} \mathrm{C}_{24}$ & 25 & 48 \\
\hline $\mathrm{Ta}_{20} \mathrm{Zr}_{12} \mathrm{C}_{32}$ & 37,5 & 64 \\
\hline $\mathrm{Ta}_{12} \mathrm{Zr}_{12} \mathrm{C}_{24}$ & 50 & 48 \\
\hline $\mathrm{Ta}_{12} \mathrm{Zr}_{20} \mathrm{C}_{32}$ & 62,5 & 64 \\
\hline $\mathrm{Ta}_{6} \mathrm{Zr}_{18} \mathrm{C}_{24}$ & 75 & 48 \\
\hline $\mathrm{Ta}_{4} \mathrm{Zr}_{28} \mathrm{C}_{32}$ & 87,5 & 64 \\
\hline
\end{tabular}

The mixing enthalpies $\Delta H$ of the solid solutions at zero pressure were calculated as the differences between the total energies $E$ of the alloy and the concentration average of end member compounds obtained at equilibrium volumes (Equation 1).

$\Delta \mathrm{H}\left((\mathrm{TaC})_{\mathrm{x}}(\mathrm{ZrC})_{1-\mathrm{x}}\right)=E_{(\operatorname{TaC})_{x}(\operatorname{ZrC})_{1-x}}-x \cdot E_{T a C}-(1-x) \cdot E_{\operatorname{ZrC}}$

As follows from Eq. (1), we focus on the stability of the solid solution with respect to decomposition into end members compounds on the same underlying crystal lattice with 
an ideal stoichiometry. It is known that refractory carbides and their solid solution may exhibit substantial off-stoichiometry on the carbon sublattice due to the formation of vacancies, which may strongly affect phase stability [47-49]. However, their modeling goes beyond the subject matter of the present work.

\subsection{Fabrication}

The following initial reagents were used for the synthesis of complex carbides $\mathrm{Ta}_{\mathrm{x}} \mathrm{Zr}_{1-\mathrm{x}} \mathrm{C}(\mathrm{x}=0.9,0.8,0.6,0.3)$ : PTsRK-1 grade zirconium powder (TU 48-4-234-84, particles size $d<15 \mu \mathrm{m}$, impurities, w.\%: Fe - 0.3, Cl - 0.003, F - 0.01, H - 0.2, C - 0.25, Ca - 0.15, Mg - 0.15), TaPM grade tantalum powder (TU 647РК30054230-436-2000, particles size $d<150 \mu \mathrm{m}$; impurities, w.\%: $\mathrm{O}$ - 0,9; $\mathrm{W}$ - 0,02; Ti, $\mathrm{Mo}, \mathrm{N}, \mathrm{Al}, \mathrm{Cu}$ - по 0,01; Co, Na, Cr - traces), P-804T grade carbon black (TU 38-1154-88). To ensure the complete conversion in the combustion front as well as the homogeneous distribution of the components in the solid solutions, we used the mechanical activation (MA) of Ta-ZrC reaction mixtures. Mechanical activation decreases the heterogeneity scale in the reaction mixture, thus enhancing the reactivity of the mixture. MA was conducted in planetary ball mill “AIR-0.015” equipped with the steel jars and steel balls ( $\mathrm{d}=1.2 \mathrm{~mm}$ ). MA regime: rotational speed - 250 rotations per minutes (rpm), balls to mixture weights ratio - 20:1, MA duration - 10 min. For more information concerning the MA of Ta-Zr-C reaction mixture, see [16-18].

SHS of $\mathrm{Ta}_{\mathrm{x}} \mathrm{Zr}_{1-\mathrm{x}} \mathrm{C}(\mathrm{x}=0.9,0.8,0.6,0.3)$ solid solutions was carried out in the "sand mold" using the Ti-C-B mixture as the "chemical oven" (a highly exothermic mixture with a combustion temperature of $3200 \mathrm{~K}$ ) to decrease the ratio of cooling of the combustion products and to increase the duration of their thermal relaxation. Reaction mixture to "chemical oven" mass ratio was equal to 1. [16,17] Powders of $\mathrm{Ta}_{\mathrm{x}} \mathrm{Zr}_{1-\mathrm{x}} \mathrm{C}$ solid solutions were prepared by grinding of combustion products in a jaw crusher until granules $<0.5 \mathrm{~mm}$ in size were obtained. The granules were then ball milled in a 3-L mill using steel jars and steel balls $(\mathrm{d}=1.2 \mathrm{~mm}$, ratio between the weights of the granules and the balls - 1:6, duration of ball milling - $6 \mathrm{~h}$ ). After the milling, the powders were treated by $10 \% \mathrm{HCl}$ solution to remove the iron admixtures and then washed using distilled water.

Bulk specimens of the $\mathrm{Ta}_{\mathrm{x}} \mathrm{Zr}_{1-\mathrm{x}} \mathrm{C}$ solid solutions ( $\mathrm{x}=0.9,0.8,0.6,0.3$ ) were produced by the hot-pressing (HP) of the powders using the DSP-515 SA Direct Hot 
Pressing setup (Dr. Fritsch Sondermaschinen GmbH, Germany). The HP parameters were as following: temperature $-2000^{\circ} \mathrm{C}$; compaction pressure $-50 \mathrm{MPa}$, dwelling time -10 $\min$.

\subsection{Characterization}

Microstructural and EDS analyses of the consolidated samples were performed using a scanning electron microscope (SEM) Hitachi S-3400N equipped with a NORAN energy dispersive spectrometer. X-ray diffraction analysis was performed on a DRON-4 diffractometer using monochromatic $\mathrm{CuK}_{\alpha}$ radiation. Point-wise recording (in the mode of step-by-step scanning) within the range of angles $2 \theta=10-110^{\circ}$, with a scan rate of $0.1^{\circ}$ and an exposure time per point of $4 \mathrm{~s}$ was employed. The resulting spectra were processed using the JCPDS database.

To investigate the phase stability of the solid solutions in the $\operatorname{Ta}_{x} \mathrm{Zr}_{1-\mathrm{x}} \mathrm{C}$ system, we annealed the hot-pressed samples in an atmosphere of argon $(\mathrm{P}=0.1 \mathrm{MPa})$ at $800{ }^{\circ} \mathrm{C}$ during the 40 h. Investigation of samples by SEM, EDS, and XRD was performed before the annealing and after 20 and $40 \mathrm{~h}$ of annealing.

\section{Results and discussion}

In Fig. 2 we provide calculated lattice parameters of the $\operatorname{Ta}_{x} \mathrm{Zr}_{1-\mathrm{x}} \mathrm{C}$ solid solutions, as well as lattice parameters of samples synthesized in this work and compare them with the available experimental data. The experimentally measured lattice parameters are in a good agreement with the calculations and with the data reported in the literature. The deviations are below $1 \%$. The slight overestimation of the calculated lattice parameter is typical for the use of the GGA. The lattice parameters manifest a linear dependence on the fraction of ZrC, corresponding to the Vegard's law [50]. The agreement seen in Fig. 2 provides strong support to the reliability of the structural model adopted in this work for simulations of the solution phases, and it confirms the accuracy of the chosen computational setup. 


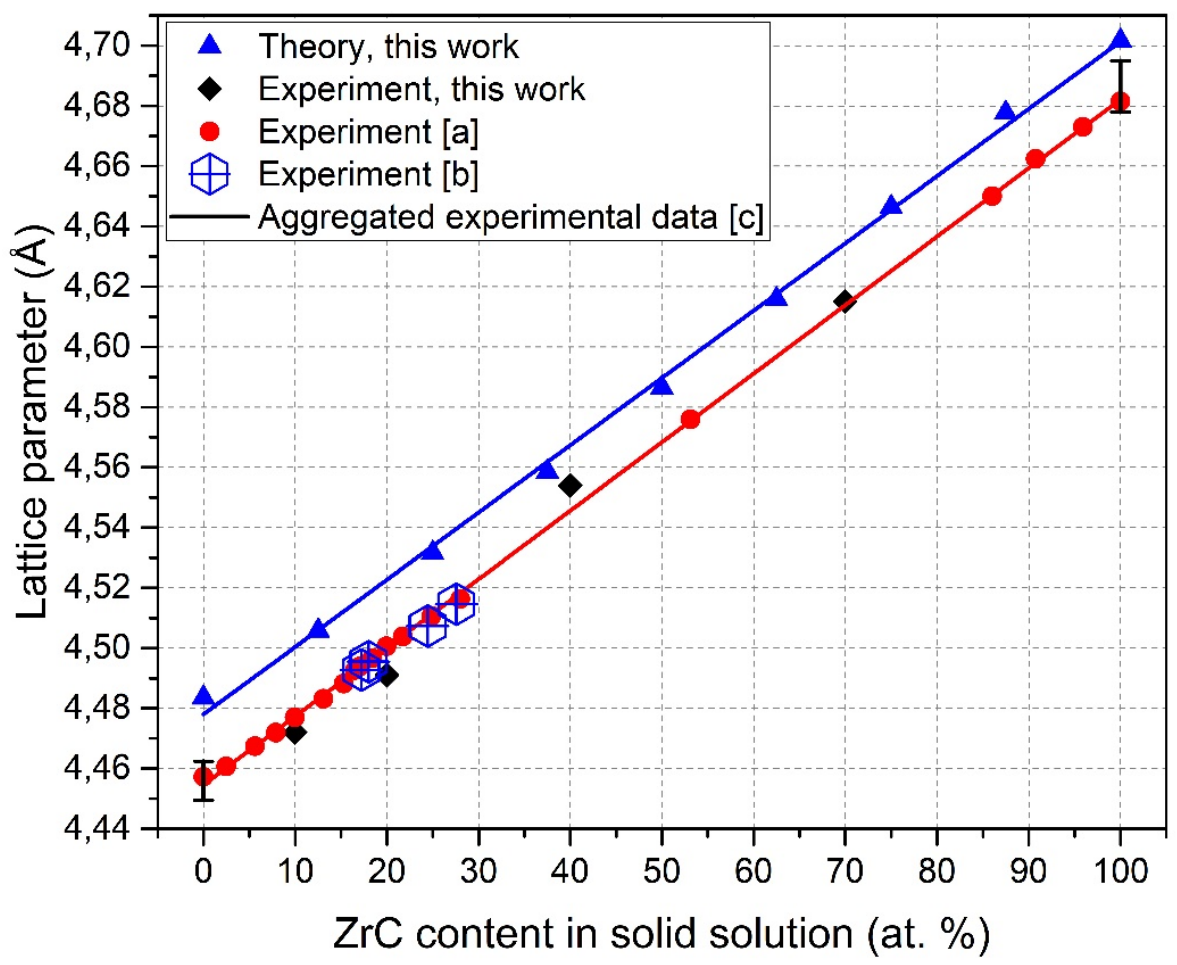

Fig. 2 - Comparison between the calculated and experimentally measured lattice parameters of the $\mathrm{Ta}_{\mathrm{x}} \mathrm{Zr}_{1-\mathrm{x}} \mathrm{C}$ system: a-[18], b-[27], c-[51].

Fig. 3 shows the calculated bulk moduli of the $\mathrm{Ta}_{\mathrm{x}} \mathrm{Zr}_{1-\mathrm{x}} \mathrm{C}$ system. For the end member compounds, the calculated results are in good agreement with all referenced experimental and computational data. For the solution phases, the bulk moduli decrease linearly with increasing fraction of $\mathrm{ZrC}$, showing that the $\mathrm{ZrC}$ significantly increases the compressibility of the alloy and provides opportunities for optimizing the mechanical response of the engineering materials in this system. 


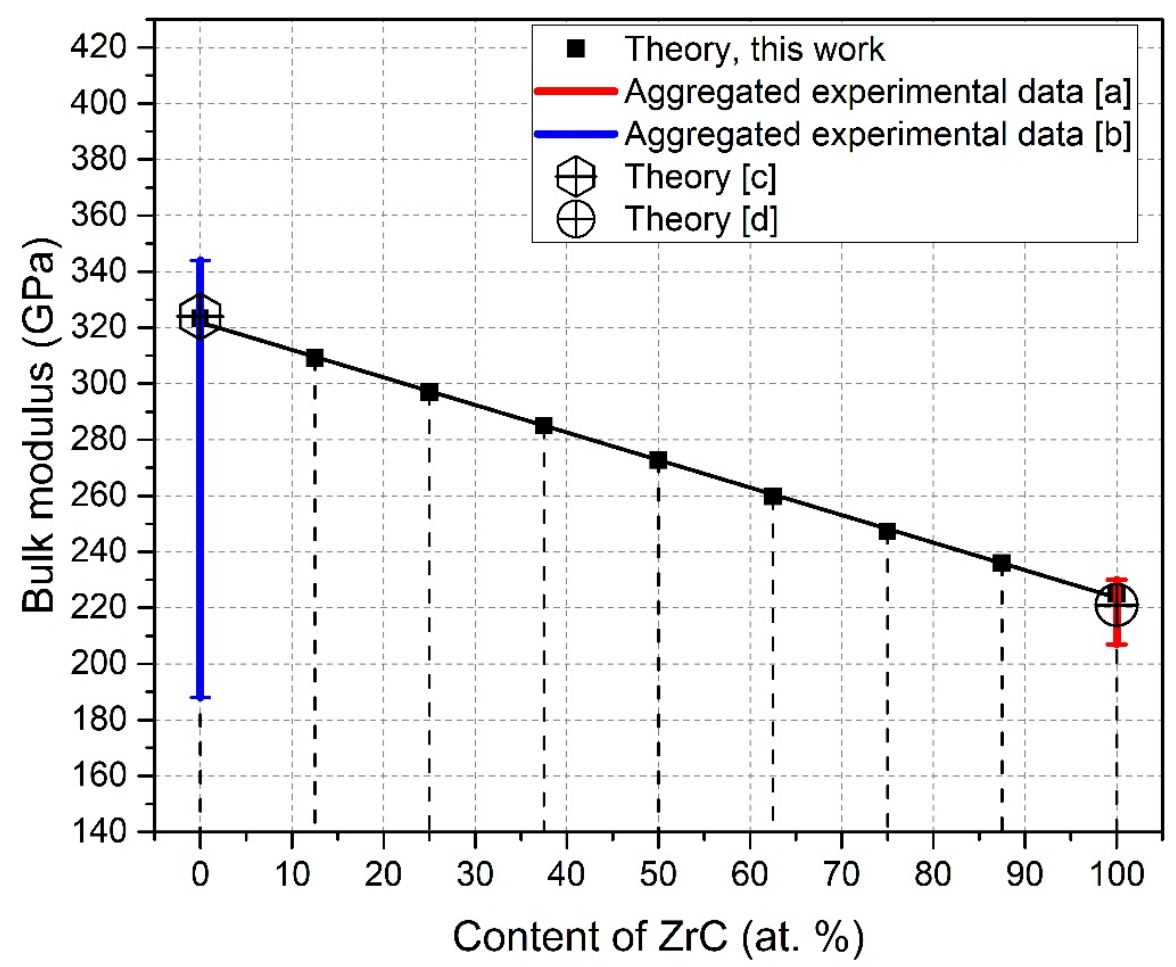

Fig. 3 - Calculated bulk moduli for the $\operatorname{Ta}_{x} \mathrm{Zr}_{1-\mathrm{x}} \mathrm{C}$ solid solutions. a-[52-54]; b-[55-59], c-[60], d-[61].

The calculated mixing enthalpies of $\mathrm{Ta}_{\mathrm{x}} \mathrm{Zr}_{1-\mathrm{x}} \mathrm{C}$ solid solutions are presented in Fig.4. The enthalpy remains negative in the whole interval of concentrations, though the absolute values are quite low. The negative enthalpy suggests the stability of the solution phase with respect to decomposition into end member compounds, $\mathrm{TaC}$ and $\mathrm{ZrC}$. The wide miscibility gaps of the type shown in Fig. 1 are usually associated with high positive values of the mixing enthalpy $[44,46]$, and therefore are highly unlikely to be present in $\mathrm{Ta}_{\mathrm{x}} \mathrm{Zr}_{1-\mathrm{x}} \mathrm{C}$ system.

Interestingly, our small negative values of $\Delta H$ calculated for the solid solutions are still somewhat lower than the corresponding values calculated in [30] for L12 ( $\mathrm{Ta}_{0.75} \mathrm{Zr}_{0.25} \mathrm{C}$ and $\mathrm{Ta}_{0.25} \mathrm{Zr}_{0.75} \mathrm{C}$ ) and $\mathrm{L} 10\left(\mathrm{Ta}_{0.5} \mathrm{Zr}_{0.5} \mathrm{C}\right.$ ) ordered structures. Therefore, the ground state ordered structures should have a more complex type of ordering than L12/L10. However, the full ground state search is beyond the subject matter of this work. 
The tendency towards ordering between $\mathrm{Ta}$ and $\mathrm{Zr}$ atoms on the metal sublattice should be quite weak, and the order/disorder transition temperature is expected to be quite low. Diffusion is extremely slow in refractory materials because of the strong chemical bonds in them. Hence, observing the decomposition of the solid solution into a mixture of ordered phases (like in a classic example of $\mathrm{Cu}-\mathrm{Au}$ ) would be a challenging experimental task. Our theoretical calculations, therefore, provide strong support to the assessment made by Rudy [27], rather than to the those made by Gusev [29] and Zhou [31] (Fig.1).

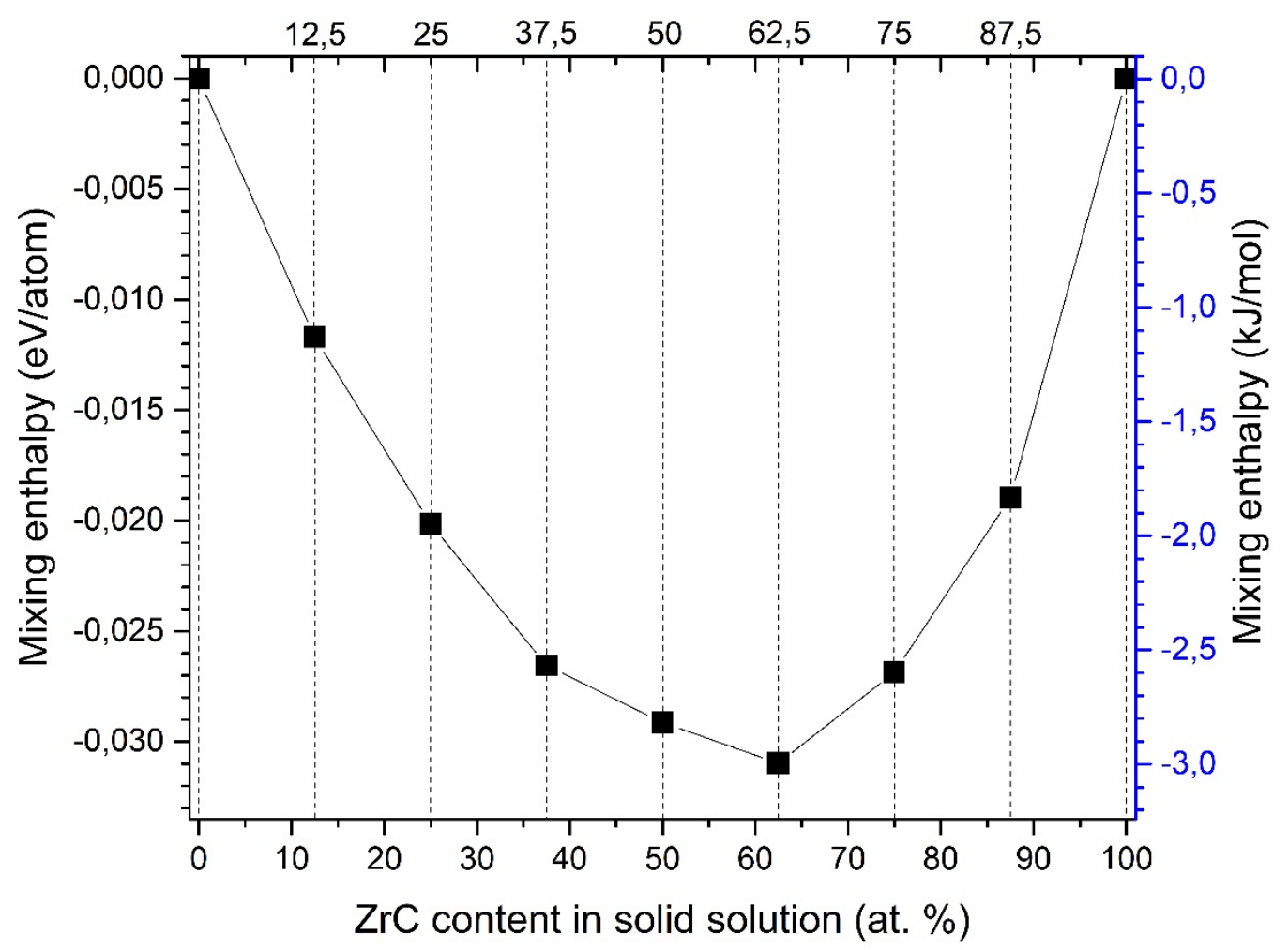

Fig. 4 - Calculated mixing enthalpy $\Delta H$ for the $\operatorname{Ta}_{x} Z_{1-x} \mathrm{C}$ solid solutions. For more information, see Table 1 in Supplemental File 1

In addition to the $a b$ initio calculations, phase stability of $\mathrm{Ta}_{\mathrm{x}} \mathrm{Zr}_{1-\mathrm{x}} \mathrm{C}$ solid solutions was examined by annealing of $\mathrm{Ta}_{\mathrm{x}} \mathrm{Zr}_{1-\mathrm{x}} \mathrm{C}$ specimens $(\mathrm{x}=0.9,0.8,0.6,0.3)$ during 40 hours at $800^{\circ} \mathrm{C}$. The temperature was chosen correspondingly to the supposed miscibility gaps (Fig. 1). As was demonstrated in [62] for the similar system Nb-Zr-C, annealing during 
the 3 hours at temperatures $300-1000^{\circ} \mathrm{C}$ caused an evident decomposition of metastable $\mathrm{Nb}_{\mathrm{x}} \mathrm{Zr}_{1-\mathrm{x}} \mathrm{C}$ solid solutions. The diffusion coefficients in solid solutions of refractory carbides mainly depend on the atomic radius of the metallic species, which is $145 \mathrm{pm}$ for both $\mathrm{Ta}$ and $\mathrm{Nb}$ and 155 for $\mathrm{Zr}$ [63]. Coefficients of diffusion $\mathrm{D}_{0}$ are also similar for TaC and NbC (1.04 and $1.2 \mathrm{~cm}^{2} \mathrm{~s}^{-1}$, correspondingly) [64]. Therefore, we investigated the phase stability of $\mathrm{Ta}_{\mathrm{x}} \mathrm{Zr}_{1-\mathrm{x}} \mathrm{C}$ solid solutions using a methodology employed for $\mathrm{Nb}_{\mathrm{x}} \mathrm{Zr}_{1-}$ ${ }_{x} \mathrm{C}$ by Gusev [62] and compared the obtained results.

The microstructure and XRD patterns of the $\mathrm{Nb}_{\mathrm{x}} \mathrm{Zr}_{1-\mathrm{x}} \mathrm{C}$ samples altered noticeably after annealing. SEM and EDS indicated the presence of areas with high concentration gradients and $\mathrm{ZrC}$ precipitates located at the grain boundaries; also, clearly discernible ZrC peaks emerged on XRD patterns [62]. To ensure the completion of possible diffusion processes, the annealing duration for the $\mathrm{Ta}_{\mathrm{x}} \mathrm{Zr}_{1-\mathrm{x}} \mathrm{C}$ system in this research was increased tenfold as compared to the annealing of $\mathrm{Nb}_{\mathrm{x}} \mathrm{Zr}_{1-\mathrm{x}} \mathrm{C}$ specimens. Solid solutions were examined using the XRD, SEM and EDS methods first time after the synthesis, then after the hot pressing, then after 20 and 40 hours of annealing. In all cases, no signs of decomposition of solid solutions were observed. Fig. 5 provides the XRD patterns for the $\mathrm{Ta}_{\mathrm{x}} \mathrm{Zr}_{1-\mathrm{x}} \mathrm{C}$ specimens $(\mathrm{x}=0.9,0.8,0.6,0.3)$ before and after $40 \mathrm{~h}$ of annealing. The location of XRD peaks is defined by the lattice parameters, which in turn depend on the composition (Fig. 2). Annealing during the $40 \mathrm{~h}$ changes neither the location nor the number of peaks on the XRD pattern. The only noticeable difference is the slight increase of the XRD peaks intensity after the annealing, which might be caused by minor grain growth. No broadening, shifting or splitting of XRD peaks (which could indicate the decomposition of solid solutions) was observed. 

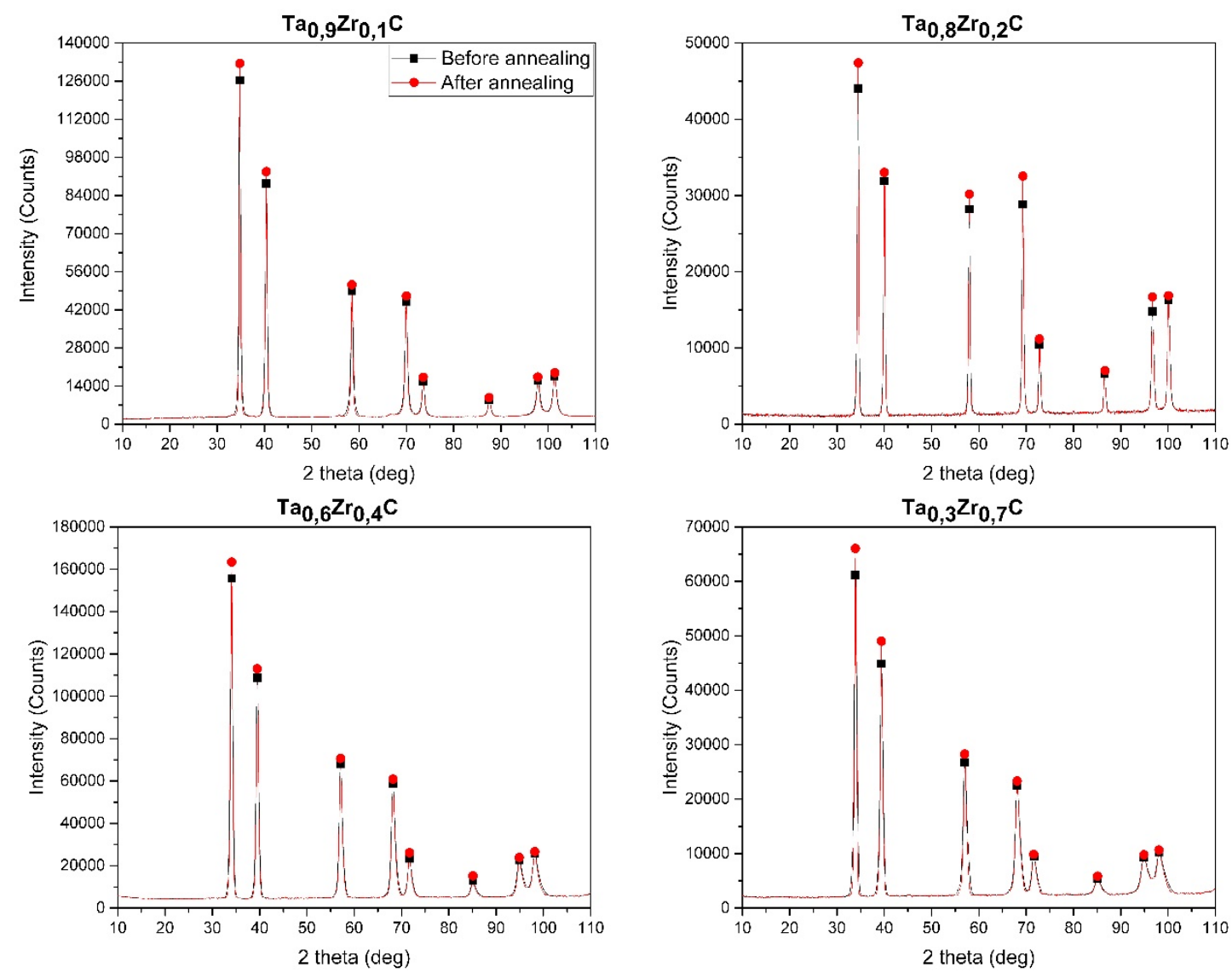

Fig. 5 - XRD patterns for the $\operatorname{Ta}_{\mathrm{x}} \mathrm{Zr}_{1-\mathrm{x}} \mathrm{C}$ specimens ( $\mathrm{x}=0.9,0.8,0.6,0.3$ ) before and after the annealing during $40 \mathrm{~h}$ at $800{ }^{\circ} \mathrm{C}$

Similarly, the microstructure and elemental composition of the $\operatorname{Ta}_{x} \mathrm{Zr}_{1-\mathrm{x}} \mathrm{C}(\mathrm{x}=0.9$, 0.8, 0.6, 0.3) specimens were not affected by the annealing (Fig. 6). No secondary-phase precipitates or noticeable concentration gradient have emerged. The contrast between the grains (Fig. 6) is crystallographic rather than compositional since the elemental composition of these grains coincides within the boundaries of EDS measurements accuracy. Black regions in Fig. 6 correspond to the pores in sintered specimens. The porosity of the hot-pressed $\operatorname{Ta}_{\mathrm{x}} \mathrm{Zr}_{1-\mathrm{x}} \mathrm{C}(\mathrm{x}=0.9,0.8,0.6,0.3)$ samples was $\approx 8 \%$. However, the samples of $\mathrm{Ta}_{0.9} \mathrm{Zr}_{0.1} \mathrm{C}$ and $\mathrm{Ta}_{0.3} \mathrm{Zr}_{0.7} \mathrm{C}$ solid solutions had smaller and more evenly distributed pores $(1-3 \mu \mathrm{m})$ as compared to the $\mathrm{Ta}_{0.8} \mathrm{Zr}_{0.2} \mathrm{C}$ and $\mathrm{Ta}_{0.6} \mathrm{Zr}_{0.4} \mathrm{C}$, where the pores were more coarse $(3-5 \mu \mathrm{m})$ and located primarily on the grain boundaries. The largest pores $(5-7 \mu \mathrm{m})$ were located on the triple grain junctions (Fig. 6 c,e). Similarly, grains size in the samples $\mathrm{Ta}_{0.8} \mathrm{Zr}_{0.2} \mathrm{C}$ and $\mathrm{Ta}_{0.6} \mathrm{Zr}_{0.4} \mathrm{C}(\approx 19$ and $\approx 22 \mu \mathrm{m})$ was somewhat higher than for $\mathrm{Ta}_{0.9} \mathrm{Zr}_{0.1} \mathrm{C}$ and $\mathrm{Ta}_{0.3} \mathrm{Zr}_{0.7} \mathrm{C}(\approx 18$ and $\approx 17 \mu \mathrm{m})$. The difference in 
microstructure suggests more active recrystallization and coalescence of the pores during the sintering of the compositions $\mathrm{Ta}_{0.8} \mathrm{Zr}_{0.2} \mathrm{C}$ and $\mathrm{Ta}_{0.6} \mathrm{Zr}_{0.4} \mathrm{C}$, probably due to higher diffusion mobility of crystal lattice defects. The annealing has lead to a minor increase in the grains size $(\leq 1 \mu \mathrm{m})$ but did not affect the porosity beyond the measurement's error margins. This effect might be related to the increased dislocation mobility reported for $\mathrm{Ta}_{\mathrm{x}} \mathrm{Hf}_{1-\mathrm{x}} \mathrm{C}$ solid solutions [19].

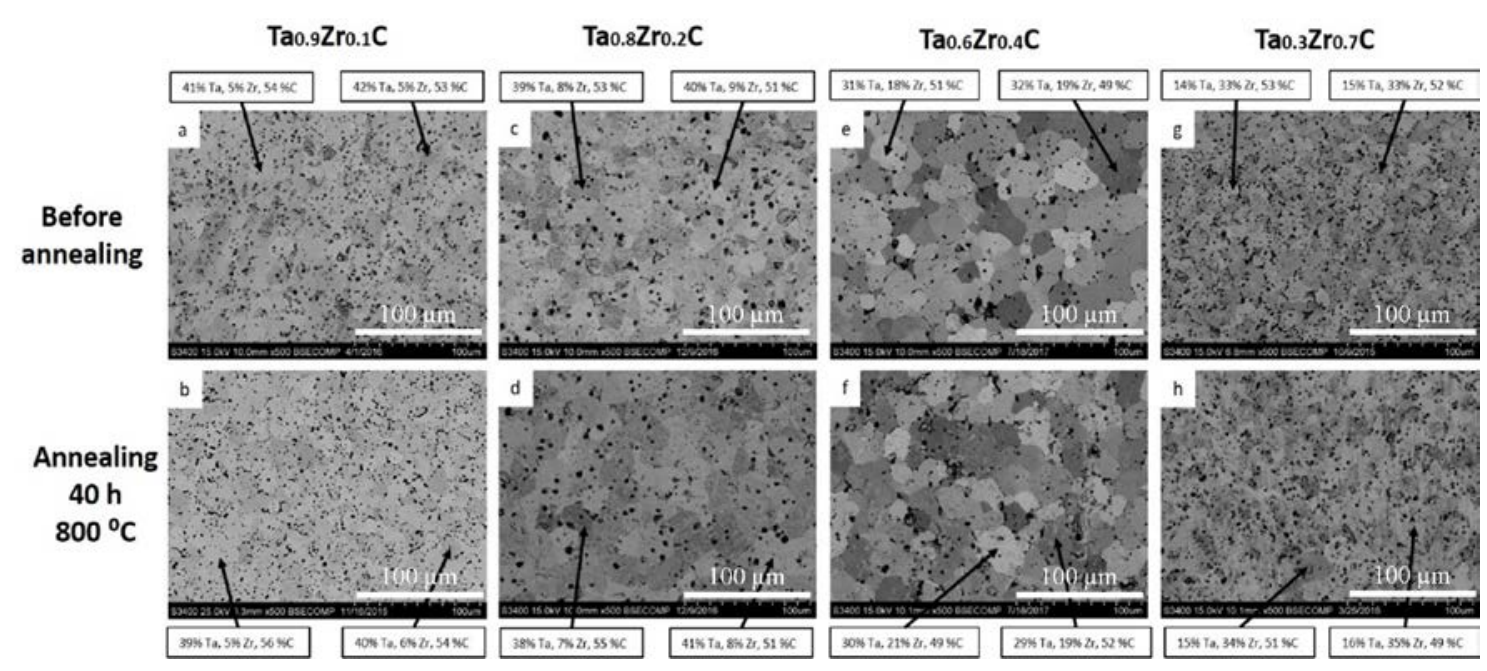

Fig. 6 - The microstructure of $\mathrm{Ta}_{\mathrm{x}} \mathrm{Zr}_{1-\mathrm{x}} \mathrm{C}$ specimens before (a,c,e,g) and after (b,d,f,h) the annealing during $40 \mathrm{~h}$ at $800{ }^{\circ} \mathrm{C}$

Given these features, some experiments [28] might have suggested a miscibility gap because the diffusion during the synthesis of the investigated samples was incomplete, and the single-phase solid solution was not produced. The incompletion of the diffusion processes might have been caused by the insufficient chemical purity of the used reagents, by the contamination of the material during the synthesis by oxygen or auxiliary reagents, as well as by insufficient temperatures and dwelling times used for the production of the single-phase solid solutions.

\section{Conclusions}

In this work, $a b$ initio calculations and experimental investigation of the solid solutions in the $\mathrm{Ta}_{\mathrm{x}} \mathrm{Zr}_{1-\mathrm{x}} \mathrm{C}$ system were used to address controversial reports regarding the existence of the miscibility gap on the corresponding phase diagram. Calculated mixing enthalpy for the $\mathrm{Ta}_{\mathrm{x}} \mathrm{Zr}_{1-\mathrm{x}} \mathrm{C}$ solid solutions is found to be negative in the whole 
interval of concentrations, suggesting the stability of the solid solution with respect to decomposition into the end member compounds. In agreement with calculations, annealing of the $\operatorname{Ta}_{x} \mathrm{Zr}_{1-\mathrm{x}} \mathrm{C}(\mathrm{x}=0.9,0.8,0.6,0.3)$ specimens during the $40 \mathrm{~h}$ at the temperature of $800{ }^{\circ} \mathrm{C}$ in argon atmosphere showed no signs of decomposition of the solid solution. Thus, both $a b$ initio calculations and experiment investigation suggest the absence of the decomposition of the $\mathrm{Ta}_{\mathrm{x}} \mathrm{Zr}_{1-\mathrm{x}} \mathrm{C}$ solid solutions into end members compounds. In the case of $\mathrm{Ta}-\mathrm{Zr}-\mathrm{C}$ system, we demonstrate that the presence of the miscibility gap in the $\mathrm{Ta}_{\mathrm{x}} \mathrm{Zr}_{1-\mathrm{x}} \mathrm{C}$ phase diagram with carbon to metal ratio close to stoichiometric $(1: 1)$ is highly questionable.

\section{Acknowledgments}

Ab initio calculations were supported by the Grant of Ministry of Education and Science of the Russian Federation (Grant No. 14.Y26.31.0005). The thermodynamic analysis was supported by the Ministry of Education and Science of the Russian Federation in the framework of Increase Competitiveness Program of NUST “MISIS” (No K2-2017-080) implemented by a governmental decree dated 16 March 2013, No 211. Synthesis, hot pressing and experimental investigation of the $T a_{x} Z r_{1-x} C$ samples were supported by the Russian Science Foundation (project № 17-79-10173). IAA is grateful to the support provided by the Swedish Government Strategic Research Area in Materials Science on Functional Materials at Linköping University (Faculty Grant SFO-Mat-LiU No 200900971) and the competence center FunMat-II, financially supported by Vinnova (grant no 2016-05156).

\section{Data Availability statement}

The raw data required to reproduce these findings are available to download from http://dx.doi.org/10.17632/3tvxxym8zw.1. The processed data required to reproduce these findings are available to download from http://dx.doi.org/10.17632/3tvxxym8zw.1.

\section{References}

[1] N. P. Padture, Advanced structural ceramics in aerospace propulsion, Nat. Mater. 15 (2016) 804-809. 
[2] X-T. Shen, K-Z. Li, H-J. Li, Q-G. Fu, S-P. Li, F. Deng, The effect of zirconium carbide on ablation of carbon/carbon composites under an oxyacetylene flame. Corros Sci. 53 (2011) 105-112.

[3] R. Savino, L. Criscuolo, G. D. Di Martino, S. Mungiguerra, Aero-thermo-chemical characterization of ultra-high-temperature ceramics for aerospace applications, J. Eur. Ceram. Soc. 38(8) (2018) 2937-2953.

[4] W. G. Fahrenholtz, G. E. Hilmas, Ultra-high temperature ceramics: Materials for extreme environments, Scr. Mater. 129 (2017) 94-99.

[5] M. Kutz, Handbook of Materials Selection. Wiley, New York, 2002.

[6] X. Jin, X. Fan, C. Lu, T. Wang, Advances in oxidation and ablation resistance of high and ultra-high temperature ceramics modified or coated carbon/carbon composites, J. Eur. Ceram. Soc. 38 (1) (2018)1-28.

[7] G.-J. Zhang, D.-W. Ni, J. Zou, H.-T. Liu, W.-W. Wu, J.-X. Liu, T. S. Suzuki, Y. Sakka, Inherent anisotropy in transition metal diborides and microstructure/property tailoring in ultra-high temperature ceramics—A review, J. Eur. Ceram. Soc. 38(2) (2018) 371-389.

[8] C. Zhang, A. Loganathan, B. Boesl, A. Agarwal, Thermal Analysis of Tantalum Carbide-Hafnium Carbide Solid Solutions from Room Temperature to $1400 \circ \mathrm{C}$, Coatings. 7(8) (2017), Article 111

[9] P. Galizia, S. Failla, L. Zoli, D. Sciti, Tough salami-inspired Cf/ZrB2 UHTCMCs produced by electrophoretic deposition, J. Eur. Ceram. Soc. 38(2) (2018) 403-409.

[10] C.M. Carney, Ultra-High Temperature Ceramic-Based Composites, in: C. H. Zweben, P. Beaumont (Eds.), Comprehensive Composite Materials II, Elsevier, Oxford, 2018, pp. 281-292

[11] T. Dobatkina and N. Bochva, Carbon - Tantalum - Zirconium, in: G. Effenberg, S. Ilyenko (Eds.), Ternary Alloy Systems: Phase Diagrams, Crystallographic and Thermodynamic Data, Group IV: Physical Chemistry, Volume 11, Part 3: Selected Systems from C-Ta-W to Ti-V-W, Springer-Verlag, Berlin, 2010, pp.18-31

[12] O. Cedillos-Barraza, D. Manara, K. Boboridis, T. Watkins, S. Grasso, D. D. Jayaseelan, R. J. M. Konings, M. J. Reece, W. E. Lee, Investigating the highest melting temperature materials: A laser melting study of the TaC-HfC system, Sci. Rep. 6 (2016) Article 37962 DOI: 10.1038/srep37962. 
[13] X. Zhang, G. E. Hilmas, W. G. Fahrenholtz, Densification and mechanical properties of TaC-based ceramics, Mater. Sci. Eng.: A. 501(1-2) (2009) 37-43.

[14] I. S. Grigoriev, E. Z. Meilikhov, A. A. Radzig, Handbook of Physical Quantities, CRC Press, Boca Raton, 1996.

[15] Thompson, Gregory B., and Christopher R. Weinberger. "Tantalum carbides: their microstructures and deformation behavior." Ultra-High Temperature Ceramics: Materials for Extreme Environment Applications (2014): 291-315

[16] E.I. Patsera, E.A. Levashov, V.V. Kurbatkina, D.Yu. Kovalev, Production of UltraHigh Temperature Carbide (Ta,Zr)C by Self-Propagating High-Temperature Synthesis of Mechanically Activated Mixtures, Ceram. Int. 41(7) (2015) 8885-8893.

[17] V.V. Kurbatkina, E.I. Patsera, S.A. Vorotilo, E.A. Levashov, A.N. Timofeev, Conditions for fabricating single-phase (Ta, $\mathrm{Zr}$ )C carbide by SHS from mechanically activated reaction mixtures, Ceram. Int. 42(15) (2016) 16491-16498.

[18] V. V. Kurbatkina, E. I. Patsera, E. A. Levashov, S. Vorotilo, SHS Processing and Consolidation of Ta-Ti-C, Ta-Zr-C and Ta-Hf-C Carbides for Ultra-High-Temperatures Application. Adv. Eng. Mater. (In press) doi 10.1002/adem.201701075.

[19] C. J. Smith, X.-X. Yu, Q. Guo, C. R. Weinberger, G. B. Thompson, Phase, hardness, and deformation slip behavior in mixed HfxTa1-xC, Acta Mater. 145 (2018) 142-153 [20] Qi-Jun Hong, A. van de Walle, Prediction of the material with highest known melting point from ab initio molecular dynamics calculations. Phys. Rev. B. 92 (2015) Article 020104(R)

[21] O. Cedillos-Barraza, S. Grasso, N. A. Nasiri, D. D. Jayaseelan, M. J. Reece, W. E. Lee, Sintering behaviour, solid solution formation and characterisation of TaC, HfC and TaC-HfC fabricated by spark plasma sintering, J. Eur. Ceram. Soc. 36(7) (2016) 1539_ 1548.

[22] A.S. Rogachev, A.S. Mukasyan, Combustion for Material Synthesis. CRC Press, Boca Raton, 2014.

[23] Concise Encyclopedia of Combustion Synthesis: History, Theory, Technology, and Products (Eds. I. Borovinskaya, A. Gromov, Yu. Maksimov, A. Rogachev, E. Levashov, A. Mukasyan), Elsevier, Toronto, 2017.

[24] A.G. Merzhanov, Combustion processes that synthesize materials, J. Mater. Process. Techol. 56 (1996) 222-241. 
[25] E.I. Gladyshevsky, T.F. Fedorov, L.V. Gorshkova. The zirconium-tantalum-carbon system. Russ. J. Inorg. Chem. 9 (1964) 639-642.

[26] A.I. Avgustinik, S.S. Ordan'yan. Structure of alloys of Zr-C-Ta system. Zh. Prikl. Kim. 39(2) (1966) 318-323.

[27] E. Rudy, Section III: Zr-Ta-C System. Ternary phase equilibria in transition metalboron-carbon-silicon systems, Techn. Rep. AFML-TR-65-2 1969 334-360

[28] G.Jangg, R.Kieffer, L.Usner, Gewinnung von Mischkarbiden aus dem Hilfsmetallbad, J. Less-Comm. Met. 14 (1968) 269-277.

[29] A.I. Gusev, Order-Disorder Transformations and Phase Equilibria in Strongly Nonstoichiometric Compounds, Phys.-Uspekhi, 43(1) (2000) 1-37, translated from Usp. Fiz. Nauk, 170(1) (2000) 3-40.

[30] A. Markström, D. Andersson, K. Frisk. Combined ab-initio and experimental assessment of A1-xBxC mixed carbides. CALPHAD: Comput. Coupling Phase Diagrams Thermochem. 32 (2008) 615-623.

[31] P. Zhou, Y. Peng, Y. Du, S. Wang, G. Wen, W. Xie, K. Chang, A thermodynamic description of the C-Ta-Zr system. Int. J. Refract. Met. Hard Mater. 41 (2013) 408-415. [32] S.A. Ghaffari, M.A. Faghihi-Sani, F. Golestani-Fard, M. Nojabayy. Diffusion and solid solution formation between the binary carbides of TaC, HfC and $\mathrm{ZrC}$, Int. J. Refract. Met. Hard Mater. 41 (2013) 180-184

[33] X-X Yu, C.R. Weinberger, G.B. Thompson. Ab initio investigations of the phase stability in group IVB and VB transition metal carbides. Comput Mater Sci 112 (2016) 318-326

[34] X-X Yu, C.R. Weinberger, G.B. Thompson. Ab initio investigations of the phase stability in tantalum carbides. Acta Mater 80 (2014) 341-349

[35] Xie C, Oganov AR, Li D, Debela TT, Liu N, Dong D, et al. Effects of carbon vacancies on the structures, mechanical properties, and chemical bonding of zirconium carbides: a first-principles study. Phys Chem Chem Phys. 2016;18(17):12299-306

[36] Zhang Y., Liu B., Wang J. Self-assembly of Carbon Vacancies in Sub-stoichiometric ZrC1-x. Scientific Reports, 2015; 5: 18098.

[37] P.E. Blöchl, Projector augmented-wave method, Phys. Rev. B 50 (1994) 1795317979. 
[38] A. I. Duff, T. Davey, D. Korbmacher, A. Glensk, B. Grabowski, J. Neugebauer, M. W. Finnis, Improved method of calculating $a b$ initio high-temperature thermodynamic properties with application to ZrC, Phys. Rev. B 91 (2015) 214311-1 - 214311-8.

[39] G. Kresse, J. Furthmuller, Efficiency of ab-initio total energy calculations for metals and semiconductors using a plane-wave basis set, Comput. Mater. Sci. 6 (1996) 15-50. [40] G. Kresse, J. Hafner, Ab initio molecular dynamics for liquid metals, Phys Rev. B, 47(1) (1993) 558-561.

[41] G. Kresse, D. Joubert, From ultrasoft pseudopotentials to the projector augmentedwave method, Phys. Rev. B 59 (3) (1999) 1758-1775.

[42] KG. Kresse, J. Furthmuller, Efficient iterative schemes for ab initio total-energy calculations using a plane-wave basis set, Phys. Rev. B , 54(16) (1996) 11169-11186.

[43] A. Zunger, S.-H. Wei, L.G. Ferreira, J.E. Bernard, Special quasirandom structures, Phys. Rev. Lett. 65 (1990) 353-356.

[44] B. Alling, A. V. Ruban, A. Karimi, O. E. Peil, S. I. Simak, L. Hultman, I. A. Abrikosov, Mixing and decomposition thermodynamics of $\mathrm{c}-\mathrm{Ti} 1-\mathrm{x} \mathrm{Al} \mathrm{x} \mathrm{N} \mathrm{from} \mathrm{first-}$ principles calculations, Phys. Rev. B 75 (2007) Article 045123.

[45] H.J. Monkhorst, J.D. Pack, Special points for Brillouin-zone integrations, Phys. Rev. В 135 (1976) 5188-5192.

[46] B. Alling, A. Karimi, I.A. Abrikosov. Electronic origin of the isostructural decomposition in cubicM1-xAlxN (M=Ti, Cr, Sc, Hf): A first-principles study. Surf. Coat. Technol. 203 (2008) 883-886.

[47] Gusev, Aleksandr Ivanovich, Andrej A. Rempel, and Andreas J. Magerl. Disorder and order in strongly nonstoichiometric compounds: transition metal carbides, nitrides and oxides. Vol. 47. Springer Science \& Business Media, 2013.

[48] Weinberger, Christopher R., and Gregory B. Thompson. "Review of Phase Stability in the Group IVB and VB Transition Metal Carbides." Journal of the American Ceramic Society, 2018. https://doi.org/10.1111/jace.15768

[49] Gusev, Aleksandr Ivanovich. "Order-disorder transformations and phase equilibria in strongly nonstoichiometric compounds." Physics-Uspekhi 43.1 (2000): 1-37.

[50] A. R. Denton, N. W. Ashcroft. Vegard's law. Phys. Rev. A 43 (1991) 3161-3164.

[51] G. Chiarotti. Landolt-Börnstein - Group III Condensed Matter 24a. SpringerMaterials Berlin Heidelberg 1993. 
[52] Green D.J. An Introduction to the Mechanical Properties of Ceramics. Cambridge University Press, (1998), 210

[53] Yang Q., Lengauer W., Koch T., Scheerer M. and Smid I. Hardness and elastic properties of $\operatorname{Ti}(\mathrm{CxN1} 1-\mathrm{x}), \operatorname{Zr}(\mathrm{CxN1} 1-\mathrm{x})$ and $\mathrm{Hf}(\mathrm{CxN1} 1-\mathrm{x})$. Journal of Alloys and Compounds Volume 309, Issues 1-2, 14 September 2000, Pages L5-L9.

[54] Brown H.L. and Kempter C.P. Elastic properties of zirconium carbide. Phys. Status Solidi 18(1), (1966), K21-K23

[55] D.J. Rowcliffe, W.J. Warren, Structure and properties of tantalum carbide crystals, J. Mater. Sci. 5 (1970) 345-350.

[56] R.W. Bartlett, C.W. Smith, Elastic constants of tantalum monocarbide, TaC0.90, J. Appl. Phys. 38 (1967) 5428-5429.

[57] H.L. Brown, P.E. Armstrong, C.P. Kempter, Elastic properties of some policrystalline transition-metal monocarbides, J. Chem. Phys. 45 (2) (1966) 547-549.

[58] C.K. Jun, P.T.B. Shaffer, Elastic moduli of niobium carbide and tantalum carbide at high temperature, J. Less-Common Met. 23 (1971) 367-373.

[59] S. Haussuhl, Handbook of Elastic Properties of Solids, Liquids, and Gases, vol. I, Academic Press, San Diego, 2001.

[60] L. López-de-la-Torre, B. Winkler, J. Schreuer, K. Knorr, M. Avalos-Borja,. Elastic properties of tantalum carbide (TaC). Solid State Communications, 134(4), (2005) 245250. doi:10.1016/j.ssc.2005.01.036

[61] Yang, X.-Y., Lu, Y., Zheng, F.-W., \& Zhang, P. (2015). Mechanical, electronic, and thermodynamic properties of zirconium carbide from first-principles calculations. Chinese Physics B, 24(11), 116301. doi:10.1088/1674-1056/24/11/116301

[62] S.V. Rempel, A.I. Gusev, Surface segregation of ZrC from a carbide solid solution, Phys. Solid State 44 (2002) 68-74.

[63] J.C. Slater (1964). "Atomic Radii in Crystals". J. Chem. Phys. 41: 3199. doi:10.1063/1.1725697.

[64] T.C. Wallace, D.P. Butt, Review of diffusion and vaporization of Group 4 and 5 transition metal carbides. in: The chemistry of transition metal carbides and nitrides. Ed. S.T. Oyama. Blackie academic \& professional, 1996, pp.53-89 